\title{
Efektifitas promosi kesehatan oleh kader terhadap sikap dan perilaku pencegahan HIV/AIDS di Balecatur Yogyakarta
}

\author{
Dhesi Ari Astuti ${ }^{1}$, Nurul Kurniati ${ }^{1}$, Mega Ardina ${ }^{2}$ \\ ${ }^{1}$ Program Studi Kebidanan, Fakultas IImu Kesehatan, Universitas Aisyiyah Yogyakarta, \\ Indonesia \\ ${ }^{2}$ Program Studi Komunikasi, Fakultas Ekonomi IImu Sosial dan Humaniora, Universitas \\ Aisyiyah Yogyakarta, Indonesia
}

\begin{abstract}
HIV / AIDS is one of the biggest challenges to socio-economic development, defense of developing countries. Promotive efforts as part of the Sustainable Development Goals (SDGs) must be implemented. Implementation of activities in health promotion required by media promotion in various ways to be used by health promotion to deliver health messages, provide or enhance knowledge and attitudes about health or transform health to target. Health cadres have been proven in previous studies to have influence in knowledge, attitudes or behavior. The purpose of this study was to describe the effectiveness of HIV / AIDS cadres on HIV AIDS attitudes and protection in mothers in Balecatur Gamping Village, Sleman, Yogyakarta. This research method is quasiexperimental with pre test and post test design with statistical analysis of Paired $T$ test. The results of this study are statistics do not include differences in the average attitude ( $p$-value $=0.507)$ and there is no difference in the average risk prevention policy ( $p$-value $=0.693$ ) respondents who are accompanied by cadres who help before and during mentoring. The conclusion that assistance by cadres in Balecatur is not a major factor in health promotion to improve attitudes and protection against HIV / AIDS.
\end{abstract}

Keywords: attitude, behavior, HIV / AIDS prevention

HIV/AIDS merupakan salah satu ancaman terbesar terhadap pembangunan sosial ekonomi, stabilitas negaranegara berkembang. Upaya promotif sebagai bagian dari Sustainable Development Goals (SDGs) harus diimplementasikan. Implementasi kegiatan dalam promosi kesehatan diperlukan media promosi dengan berbagai cara untuk digunakan oleh pelaku promosi kesehatan untuk menyampaikan pesan-pesan kesehatan, memberikan atau meningkatkan pengetahuan dan sikap tentang kesehatan atau mentransformasikan perilaku kesehatan kepada sasaran. Kader kesehatan telah dibuktikan dalam penelitian-penelitian sebelumnya memiliki pengaruh dalam pengetahuan, sikap atau perilaku. Tujuan penelitian ini untuk mengetahui efektifitas kader HIV/AIDS terhadap sikap dan perilaku pencegahan HIV AIDS pada ibu di Desa Balecatur Gamping Sleman Yogyakarta. Metode penelitian ini dengan quasi-experimental study dengan pre test dan post test dengan analisis uji statistik Paired T test. Hasil penelitian ini secara statistik tidak terdapat perbedaan rerata sikap ( $p$-value $=0,507)$ dan tidak terdapat perbedaan rerata perilaku pecegahan berisiko $(p$-value $=0,693$ ) responden yang didampingi oleh kader yang bermakna sebelum dan sesudah satu kali pendampingan. Kesimpulan pendampingan oleh kader di Balecatur bukan merupakan faktor utama dalam promosi kesehatan untuk peningkatan sikap dan perilaku pencegahan terhadap HIV/AIDS.

Kata kunci: Pencegahan HIV/AIDS, Perilaku, Sikap

\footnotetext{
Korespondensi Penulis: Dhesi Ari Astuti (email : dhesi_stikesayo@yahoo.co.id)
} 


\section{Pendahuluan}

Kejadian HIV/AIDS masih menjadi masalah global. Pada tahun 2015, sebanyak 36,7 juta penduduk dunia terkena HIV dan 1,1 juta terkena AIDS. Sekitar 5700 orang terkena HIV setiap harinya. Di Indonesia, HIV/AIDS pertama kali di temukan di Provinsi Bali pada tahun 1987. Kementerian Kesehatan Republik Indonesia telah menyatakan sampai 2010 bahwa kasus AIDS yang ada di Indonesia sudah berjumlah 24.131 kasus yang tersebar di 300 kabupaten/kota di Indonesia (Kemenkes, 2014). Indonesia merupakan negara dengan angka kejadian HIV/AIDS yang cukup tinggi. Pada tahun 2015, kejadian HIV di Indonesia sebanyak 30.935 orang dan AIDS sebanyak 7.185 orang (Kemenkes RI, 2017).

Berdasarkan data tahun 2018 dari Kepala Seksi Pencegahan dan Pengendalian Penyakit Menular, Bidang Penanggulangan Penyakit Dinas Kesehatan Kabupaten Sleman Yogyakarta mencatat kasus HIV di wilayah setempat jumlahnya tertinggi di bandingkan kabupaten/kota di Provinsi Daerah Istimewa Yogyakarta. yaitu mencapai 915 kasus, Kota Yogyakarta dengan 859 kasus dan Kabupaten Bantul dengan 857 kasus, dan yang paling sedikit di Kabupaten Kulon Progo yang hanya 201 kasus.
Berdasarkan penelitian (Astuti, 2014) banyak faktor yang berhubungan untuk test HIV pada WPSTL, sepanjang jalan Wates merupakan hotspot layanan jasa

seksual yang berkedok dalam salon dan panti pijat. Pekerja seks tidak langsung ini merupakan populasi kunci penyebaran HIV/AIDS karena sering berganti-ganti pasangan dan dalam melakukan hubungan seksual tidak menggunakan pelindung berupa kondom. Hasil penelitian tersebut menyebutkan bahwa telah ada 2 pekerja seks yang positif HIV dan menjalani pengobatan antiretroviral (ARV).

Dusun Ngaran merupakan wilayah Kabupaten Sleman, namun keberadaannya dekat dengan Jalan Wates, sehingga merupakan wilayah yang berisiko dengan akses ke penjaja seks tidak

Belum ada pembinaan secara rutin ke dusun oleh petugas kesehatan setempat. Ada satu organisasi yang dibentuk di masyarakat yaitu perkumpulan ibu-ibu dasawisma yang bernama Seruni dan Mawar. Dasawisma Seruni dan Mawar mempunyai potensi yang besar utuk dikembangkan, dengan aktifitas yang dilakukan secara rutin setiap bulan seperti mengikuti lomba tertib administrasi, bina keluarga remaja, pengembangan tanaman obat keluarga, senam sehat hari Minggu dan kegiatan lainnya yang dapat menambah eksistensi perkumpulan ini. 
Pada tahun 2017, permasalahan mitra ini telah tertangani dengan pembentukan Kader HIV/ AIDS sejumlah 30 kader. Setiap kader telah berhasil mensosialisasikan kepada 5 anggota kepala keluarga. Kader telah berhasil mengajak warga untuk melakukan tes HIV sejumlah 40

orang. Kader kesehatan yaitu tenaga yang berasal dari masyarakat, dipilih oleh masyarakat itu sendiri dan bekerja secara sukarela untuk menjadi penyelenggara posyandu (Fallen, 2010). Kader keliling HIV/AIDS telah menunjukkan keberhasilan dalam mengajak warga melakukan tes Hiv, namun belum pernah diukur pengaruhnya terhadap pengetahuan, sikap dan perilaku berisiko HIV/AIDS terhadap warga. Permasalahan yang muncul saat ini adalah Kader HIV hanya terdapat di Dusun Ngaran Balecatur, sedangkan Dusun Jatisawit juga bagian dari Balecatur yang berada di Jalan Wates, sehingga merupakan daerah rentan terhadap HIV/AIDS. Oleh karena itu ingin mengembangkan program promosi kesehatan dengan metode video yang berdasarkan analisis dalam latar belakang ini menunjukkan pengaruh terhadap pengetahuan, sikap dan perilaku. Berdasarkan latar belakang di atas maka akan dilakukan pengukuran
“Efektivitas Promosi Kesehatan dengan Kader terhadap Sikap dan Perilaku Pencegahan HIV/ AIDS di Balecatur Sleman Yogyakarta".

\section{Metode}

Jenis penelitian yang digunakan adalah eksperimen semu (quasi-experiment) dengan rancangan pretest-posttest design, kelompok responden yang diberi perlakuan promosi kesehatan dengan kader keliling HIV/AIDS yang tidak memerlukan kelompok kontrol (Notoatmodjo, 2012). Populasi dalam penelitian ini adalah seluruh ibu-ibu yang terkumpul dalam kelompok dasawisma atau PKK dengan kriteria bisa membaca, tidak menderita penyakit kronis/menular dan dalam usia reproduktif. Pengambilan sampel pada penelitian ini dilakukan dengan teknik purposive sampling. Alat pengumpulan data menggunakan kuesioner yang meliputi pengetahuan, sikap dan perilaku berisiko HIV/AIDS.

\footnotetext{
Hasil dan Pembahasan

Hasil penelitian yang dilakukan mengemukakan bahwa karakteristik responden dalam penelitian antara lain sebagai berikut.
} 
Tabel 1. Karakteristik Responden Pendampingan oleh Kader

\begin{tabular}{|c|c|c|}
\hline Karakteristik & $f$ & $\%$ \\
\hline \multicolumn{3}{|l|}{ Pendidikan } \\
\hline SD & 5 & 26,3 \\
\hline SMP & 2 & 10,5 \\
\hline SMA & 8 & 42,1 \\
\hline Sarjana & 4 & 21.1 \\
\hline \multicolumn{3}{|l|}{ Status pernikahan } \\
\hline Tidak Menikah & 1 & 5,3 \\
\hline Menikah & 13 & 68,4 \\
\hline Janda & 5 & 26,3 \\
\hline \multicolumn{3}{|l|}{ Pekerjaan } \\
\hline Tidak Bekerja & 5 & 26,3 \\
\hline Bekerja & 14 & 73,7 \\
\hline
\end{tabular}

Berdasarkan table 1 menunjukkan pernikahan kader menunjukkan 13 bahwa mayoritas pendidikan pada jenjang responden $(68,4 \%)$ menikah, sedangkan menengah atas atau SMA sebanyak 8 untuk pekerjaan mayoritas ibu memiliki responden (42,1\%). Karakteristik status pekerjaan sebesar 14 responden $(73,7 \%)$.

Tabel 2. Rerata sikap dan perilaku pencegahan terhadap HIV/AIDS

\begin{tabular}{|c|c|c|c|c|c|c|}
\hline Variabel & $\mathrm{N}$ & Min & Max & Mean & $\Delta$ Mean & SD \\
\hline \multicolumn{7}{|c|}{ Sikap Kelompok Pendampingan Oleh Kader } \\
\hline Sebelum & 19 & 25 & 72,92 & 51,97 & 1,75 & 11,44 \\
\hline Sesudah & 19 & 31,25 & 83,33 & 53,72 & & 11,81 \\
\hline \multicolumn{7}{|c|}{ Perilaku Kelompok Pendampingan Oleh Kader } \\
\hline Sebelum & 19 & 64,29 & 92,86 & 81,57 & 3,39 & 8,6 \\
\hline Sesudah & 19 & 71,43 & 100 & 84,96 & & 7,48 \\
\hline
\end{tabular}

Perbedaan rata-rata sikap kelompok rata-rata perilaku kelompok pendampingan pendampingan oleh kader sebelum dan oleh kader sebelum dan sesudah intervensi sesudah intervensi sebesar 1,75. Perbedaan sebesar 3,39. 
Efektifitas promosi kesehatan oleh kader terhadap sikap dan perilaku pencegahan HIV/AIDS...

Tabel 3. Gambaran Sikap dan Perilaku terhadap pencegahan HIV/AIDS

\begin{tabular}{lc}
\hline Variabel Penelitian & $p$-value \\
\hline Sikap kelompok pendampingan oleh kader & 0,507 \\
Perilaku kelompok pendampingan oleh kader & 0,693 \\
\hline
\end{tabular}

Hasil uji statistik sikap kelompok pendampingan oleh kader dengan $\mathrm{p}$-value $=0,507$ lebih besar dari nilai $\alpha=0,05$ berarti secara statistik tidak terdapat perbedaan rerata sikap responden yang didampingi oleh kader yang bermakna sebelum dan sesudah satu kali pendampingan kader.

Hasil uji statistik perilaku kelompok pendampingan oleh kader dengan $\mathrm{p}$-value $=0,693$ lebih besar dari nilai $\alpha=0,05$ berarti secara statistik tidak terdapat perbedaan rerata perilaku pecegahan berisiko responden yang didampingi oleh kader yang bermakna sebelum dan sesudah satu kali pendampingan kader.

\section{Sikap ibu dengan pendampingan oleh Kader}

Hasil penelitian didapatkan perbedaan ratarata sikap kelompok pendampingan oleh kader sebelum dan sesudah intervensi sebesar 1,75. Adanya peningkatan sikap setelah dilakukan pendampinga oleh kader mengindikasikan kader berhasil dalam merubag pola fikir responden sehingga bisa menentukan sikap yang positif. Adanya pengingkatan pada sikap ini juga karena dengan adanya pendampingan kader akan terbentuk ikatan emosional antara responden dengan kader yang akan mempengaruhi perubahan sikap pada responden. Pemberian penyuluhan oleh kader tentang HIV/AIDS apabila diberikan secara intens dapat mempengaruhi sikap sebesar 4,206 kali lebih besar (Husaini, 2016).

Perilaku ibu dengan pendampingan oleh Kader

Hasil penelitian didapatkan perbedaan ratarata perilaku kelompok pendampingan oleh kader sebelum dan sesudah intervensi sebesar 3,39. Adanya peningkatan perilaku setelah dilakukan pendampingan oleh kader mengindikasikan kader berhasil dalam merubah perilaku responden dalam memahami adanya perilaku beresiko HIV/AIDS sehingga bisa berperilaku yang positif. Adanya pengingkatan pada perilaku ini juga karena dengan adanya pendampingan kader akan terbentuk rasa mawas diri dan lebih waspada terhadap kegiatan yang beresiko terpapar HIV/AIDS.

Efektivitas Promosi Kesehatan Kader terhadap Sikap dan Perilaku pencegahan HIV/ AIDS di Dusun Ngaran dan JatisawitBalecatur Sleman Yogyakarta

Pendamping berperan aktif sebagai agen yang memberikan masukan positif dan direktif berdasarkan pengetahuan dan pengalamannya serta bertukar gagasan dengan pengetahuan dan pengalaman masyarakat yang didampinginya, membangkitkan kesadaran masyarakat, menyampaikan informasi, melakukan konfrontasi, menyelenggarakan pelatihan bagi masyarakat 
adalah beberapa tugas yang berkaitan fungsi kader sebagai pendamping.

Promosi kesehatan melalui kader keliling lebih efektif didukung oleh (Nelson et al., 2016) bahwa pendampingan menggunakan mentor dianggap menjadi metode pelatihan yang layak, dapat diterima, dan berkelanjutan untuk peningkatan kapasitas. Pendampingan ini sangat relevan untuk pengaturan dengan prevalensi HIV karena tidak membutuhkan biaya yang mahal. Penelitian (Jennings et al., 2016) menyebutkan pendampingan memiliki potensi untuk meningkatkan pengetahuan HIV/AIDS dengan menghilangkan mitos HIV dan meningkatkan keyakinan HIV/AIDS yang diinginkan dan sikap pencegahan terhadap HIV.

Penelitian lain yang mendukung bahwa pendampingan sangat berpengaruh dalam (Shroufi et al., 2013) yang menyebutkan bahwa program pendampingan mother to mother sangat bermanfaat dalam memberikan banyak informasi sehingga membawa perubahan perilaku yang bermanfaat. Selanjutnya, pada secara statistik tidak terdapat perbedaan antara teori yang menyebutkan bahwa perubahan sikap selain dipengaruhi oleh pengetahuan yakni pengalaman pribadi, media massa dan pengaruh atau intervensi dari orang lain dapat menjadi dasar pembentukkan sikap. Pengalaman pribadi berpengaruh pada pembentukan sikap, Middlebrook (Azwar, 2007) menyebutkan tidak adanya pengalaman yang dimiliki oleh seseorang dengan suatu objek psikologis, cenderung akan membentuk sikap negative. Sikap akan lebih mudah terbentuk jika yang dialami seseorang terjadi dalam situasi yang melibatkan factor emosional. Situasi yang melibatkan emosi akan menghasilkan pengalaman yang lebih mendalam dan lebih lama membekas.

\section{Kesimpulan}

Pendampingan kader secara intensif sangat berpengaruh dalam memberikan banyak informasi sehingga diharapkan dapat membawa perubahan perilaku. Hasil penelitian menyebutkan tidak ada perbedaan rerata sikap dan prilaku pencegahan terhadap HIV/AIDS setelah memperoleh pendampingan oleh kader sebanyak satu kali pendampingan. Kesimpulan penelitian ini mengungkapkan bahwa pendampingan oleh kader di Balecatur bukan merupakan satu-satunya upaya dan faktor utama dalam promosi kesehatan untuk peningkatan sikap dan perilaku pencegahan terhadap HIV/AIDS.

\section{Daftar Pustaka}

Astuti, D. A. (2014). Factors associated with higher uptake for HIV testing among indirect female sex workers (FSWs) in Yogyakarta Indonesia. Proceedings of the International Conference on Research, Implementation and Education of Mathematics and Sciences, 27-32.

Azwar. (2007). Sikap Manusia, Teori dan Pengukurannya. Pustaka Pelajar.

Fallen, R. (2010). catatan kuliah: keperawatan komunitas.

Jennings, L., Ssewamala, F. M., \& Nabunya, P. (2016). Effect of savings-led economic 
empowerment on HIV preventive practices among orphaned adolescents in rural Uganda: results from the Suubi-Maka randomized experiment. AIDS Care, 28(3), 273-282.

Kemenkes. (2014). Pedoman Nasional Tatalaksana Klinis Infeksi HIV dan Terapi Antiretroviral pada Orang Dewasa. Depkes.

Nelson, B. R., Makarewich, C. A., Anderson, D. M., Winders, B. R., Troupes, C. D., Wu, F., Reese, A. L., McAnally, J. R., Chen, X., \& Kavalali, E. T. (2016). A peptide encoded by a transcript annotated as long noncoding RNA enhances SERCA activity in muscle. Science, 351(6270), 271-275.

Notoatmodjo, S. (2012). Metodologi penelitian kesehatan.

Shroufi, A., Mafara, E., Saint-Sauveur, J. F., Taziwa, F., \& Viñoles, M. C. (2013). Mother to mother (M2M) peer support for women in prevention of mother to child transmission (PMTCT) programmes: a qualitative study. Plos One, 8(6), e64717. 